\title{
The Byzantine reception of Aristotle's Rhetoric: the 12th century Renaissance
}

Abstract: In this paper, I argue that, after centuries of neglect, a revival of interest towards Aristotle's Rhetoric took place in $12^{\text {th }}$ century Constantinople, which led to the production of a number of commentaries. In order to give an overview of the commentary tradition on the Rhetoric, I examine first the surviving extant commentaries themselves, then the information that the commentators offer regarding their preceding interpretations, and last the traces of commentaries on the Rhetoric found in other treatises. This examination will show that, at least within a specific group of scholars, the Rhetoric was studied and commented upon like never before. Finally, I attempt to explain this revival of interest, especially with respect to the role that philosophical and rhetorical education played in 12th century Byzantium.

Adresse: Dr. Melpomeni Vogiatzi, Munich School of Ancient Philosophy, LMU Lehrstuhl für Philosophie VI, Geschwister-Scholl-Platz 1, 80539 München, DeutSCHLAND; melinavogiatzi@gmail.com

The question regarding the reception of Aristotle's Rhetoric in the late antique and Byzantine period has been raised before. As early as 1865, H. Usener published an article on the reception of this Aristotelian treatise, and concluded that it was ignored by scholars of the late antique flourishing of Aristotelian studies, and also during Byzantium. In fact, he argues that aside from the two extant commentaries on the treatise, all references to the ancient commentary tradition on the Rhetoric refer to scholars who worked not on Aristotle's text, but rather on other late antique rhetorical treatises. Similarly, more recent studies, have argued that the treatise was studied neither by philosophers nor by rhetoricians in late antiquity, and that the existing Byzantine commentaries do not indicate in themselves any change in interest, since the commentators focus on the same topics as the ones studied by the rhetoricians of late

I would like to thank the Munich School of Ancient Philosophy, especially Prof. Peter Adamson and Prof. Christof Rapp for their recommendations and support. Also, I am indebted to Prof. Dieter Harlfinger and Dr. Nikos Agiotis and the anonymous referees for their feedback on this paper. 
antiquity. ${ }^{1}$ Therefore, according to the communis opinio on the reception of Aristotle's Rhetoric in Byzantium, the treatise was largely neglected by academic and intellectual circles, with the existing Byzantine commentaries on the treatise being single instances of interest in it, and even these being texts of no philosophical value written by authors with mainly practical interests (in line with their contemporary rhetorical tradition).

Against this communis opinio, I will show that scholarly interest in Aristotelian rhetorical theory, which largely disappeared prior to the Byzantine period, revived in the 12th century and produced a number of commentaries written by Aristotelian scholars. Here I mean scholars whose exegetic strategy aimed at interpreting Aristotle ex Aristotele in order to highlight the Rhetoric's compatibility with the other Aristotelian treatises. In order to sketch the history of the commentary tradition as it pertains to Aristotle's Rhetoric during Byzantium, I will first give an outline of the surviving Byzantine commentaries on the text. I will then supplement this list of existing commentaries with some evidence for the existence of additional commentaries on the Rhetoric.

\section{Anonymous and Stephanus on Aristotle's Rhetoric}

The only existing commentaries on Aristotle's Rhetoric are the ones that have been edited in the series Commentaria in Aristotelem Graeca (vol. 21.2, ed. RABE), two of which are extant, in that they cover the whole treatise, whereas other two have come down to us in fragmentary form. As mentioned above, the general consensus regarding these commentaries is that they are texts of no philosophical import, written by authors that are interested in rhetorical praxis rather than in philosophy. Therefore, a presentation of the content and aim of the existing commentaries will not only give the general context of the production of commentaries in the 12th century, but it will also challenge the communis opinio and demonstrate that the commentators are Aristotelian scholars, in the sense that they interpret Aristotle's rhetorical account on the basis of his own views as expressed in other treatises.

1 See H. Usener, Literarhistorisches. Rheinisches Museum 20 (1865), 131-137; see also TH. Conley, Aristotle's Rhetoric in Byzantium. Rhetorica 8 (1990), 29-44; IDEM, Notes on the Byzantine reception of the peripatetic tradition in rhetoric, in W.W. Fortenbaugh / D.C. Mirhady (eds.), Peripatetic rhetoric after Aristotle. New Jersey 1994, $217-242$. 
The first extant commentaries on Aristotle's Rhetoric that have come down to us are dated in the 12th century CE and are written in Constantinople by an Anonymous author and by an ancient commentator named Stephanus. Stephanus' identity has been a matter of study and the commentator has been convincingly identified with Stephanus Skylitzes, the later metropolitan of Trebizond. ${ }^{2}$ The identity of the Anonymous commentator is still a matter of controversy. It has been long ago suggested, although not proven, ${ }^{3}$ that the author is no other than Michael of Ephesus, probably on the basis of a reference to a commentary on the Rhetoric found in the commentary on the Sophistical Refutations that is usually attributed to Michael of Ephesus (CAG 2.3), ${ }^{4}$ as well as on the basis of a reference to a commentary on the Rhetoric found in a Byzantine list of Michael's works. ${ }^{5}$ Recently, C. RAmBourg defended this suggestion and argued in favour of the identification of the Anonymous commentator with Michael of Ephesus, mainly on the basis of analyzing medical and zoological examples used in the commentary on the Rhetoric that indicate, as she argues, strong interest in medicine and biology. ${ }^{6}$ This interest fits, in her view, with our knowledge of Michael as a commentator on Aristotle's biological works and as a doctor.

However, none of these arguments are enough to prove that Michael is the author of the anonymous commentary on the Rhetoric. First and foremost, the style, language, and philosophical maturity of the Anonymous author differs greatly from that of Michael of Ephesus: expressions typical in Michael's commentaries on other Aristotelian treatises are absent from the commentary on the Rhetoric, whereas the most characteristic linguistic features of the Anonymous are absent from Michael. Moreover, the commentary on the Rhetoric differs

2 Both commentaries are edited in H. RABE (ed.), Anonymi et Stephani in artem rhetoricam commentaria. CAG, 21/2. Berlin 1896. On the identity of Stephanus see W. WolsKA-Conus, À propos des scholies de Stéphanos à la Rhétorique d'Aristote: l'Auteur, l'œuvre, le milieu, in M. Berza (ed.), Actes du XIVe Congrès International des Etudes Byzantines. Bucarest 1976, 599-600. As Conus has argued, the Aristotelian commentator Stephanus is no other than Stephanus Skylitzes, the metropolitan of Trebizond. The monody on him written by his pupil Theodoros Prodromos is a good source of information regarding his life and career as a teacher of rhetoric at the school of Saint Paul, before he became metropolitan.

3 See Conley, Aristotle's Rhetoric (as footnote 1 above), 38.

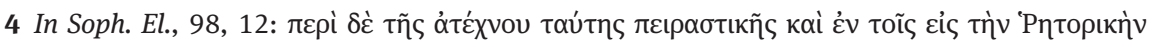

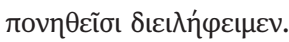

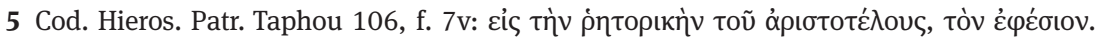

6 C. RAmbourg, Qu'est-ce que le commentaire anonyme de CAG XXI 2?, in F. Woerther (ed.), Commenting on Aristotle's Rhetoric from antiquity to the present. International Studies in the History of Rhetoric, 11. Leiden 2018, 14-40. 
greatly with respect to style from all other existing commentaries that Michael wrote. Most importantly of all, the Anonymous' commentary does not seem to have the depth of Michael's philosophical thought. ${ }^{7}$ Second, regarding Rambourg's arguments, the Anonymous' use of medical examples, and in particular, examples that come from Galen's corpus, are insufficient to prove that Michael is the author of the commentary, and indicate only that the Anonymous' is acquainted with Galen. Third, the reference to the commentary on the Sophistical Refutations cannot offer certain ground for arguing for the identity of the author, especially given that its attribution to Michael of Ephesus has recently come under scrutiny. ${ }^{8}$ The most one could infer is that there was a certain author who wrote a commentary on the Sophistical Refutations and the Rhetoric, without the further extrapolation that this commentary on the Rhetoric is the anonymous one. In fact, since the comparison of the two commentaries does not offer any positive results with respect to language, style, and content, we should conclude that the two texts have not been written by the same author, regardless of who in fact authored the commentary on the Sophistical Refutations. Finally, the reference to Michael's commentary found in the list of his works indicated earlier, is also not secure, given that other lists of Michael's commentaries do not mention the Rhetoric at all. However, even if the list is accurate and Michael has written a commentary on Aristotle's Rhetoric, this does not prove that his commentary is the one that has come down to us as anonymous. Therefore, we can conclude that the author of the anonymous commentary is not Michael of Ephesus. This conclusion will be relevant for the next section of the paper, where I will go through the evidence of further commentaries written on Aristotle's Rhetoric and I will come back to the attribution of the commentary on the Sophistical Refutations to Michael.

After dealing with the question of authorship with respect to the commentaries, an examination of their style and content will shed further light on the context in which they were written. Since my interests here are rather historical, I will focus only on the aspects of their interpretation of Aristotle's Rhetoric that can be helpful for our evaluation of their purpose. As I mentioned in the introduction, the communis opinio usually regards these commentaries as being of no

7 See C. LunA, Trois études sur la tradition des commentaires anciens à la Métaphysique d'Aristote. Philosophia antiqua, 88. Leiden 2001, 197-213; M. Vogiatzi, Byzantine commentaries on Aristotle's Rhetoric: Anonymous and Stephanus, In artem rhetoricam commentaria. Commentaria in Aristotelem Graeca et Byzantina, 8. Berlin 2019, 20 - 22.

8 Instead, the attribution of the commentary to Michael Psellos is discussed. See P. Moore, Iter Psellianum: a detailed listing of manuscript sources for all works attributed to Michael Psellos. Toronto 2005, 560. 
philosophical interest as being relevant mainly for the rhetorical practice of their time. However, I believe that this view undermines the commentaries' importance in the history of the Byzantine reception of Aristotle's Rhetoric and of Aristotle's philosophy in general. In particular, a prominent feature of both commentaries is the fact that they take Rhetoric to be a logical treatise, and in fact one that presupposes doctrines expressed in Aristotle's logical treatises. Hence, the Rhetoric is considered as being part of the Organon. The position of the Rhetoric into the Aristotelian corpus as part of the Organon has the following results: 1 . It justifies the philosopher's occupation with it. It is namely not due to its practical character, but due to its philosophical significance that students of philosophy should deal with it. 2. It explains up to a certain extent the fact that the Rhetoric has survived up to our day. In a time when more modern and more updated rhetorical treatises were available, Aristotle's Rhetoric, seen as merely handbook of rhetorical praxis, would have probably gone lost. 3. It indicates what the Byzantine commentators considered as belonging to the part of Aristotle's philosophy called logic. Although the Rhetoric is mentioned among the treatises of the Organon already during late antiquity, ${ }^{9}$ it is for the first time in these two Byzantine commentators that the Rhetoric's content is accepted and commented upon as contributing to our understanding of Aristotle's logic. ${ }^{10}$

The effort to ascribe a logical character to the treatise is more obvious in the case of Stephanus, who advances his idea of the role of the treatise by commenting only on passages that are relevant to this purpose and by interpreting passages that do not seem to be about argumentation as contributing to argumentation. Therefore, the passages of the treatise that are most obviously connected

9 See Olymp., Proleg., 8, 4-28; Simpl., In Cat., 8, 2-5; Philop., In Cat., 5, 8-14; Ammon., In Pr.An., 11, 21 -38. Elias, Proleg., 21, 18 -24; 22, 3-23, 4; In Cat., 116, 34; David, Proleg., 5, 10-12; 40, 33-41, 36; Ammonius, In Isag., 8, 4-17. On the rhetorical use of the logical prin-

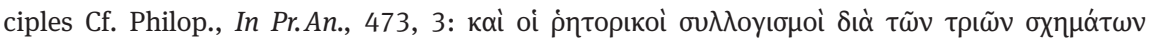

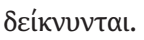

10 For instance, Olympiodorus divides the logical treatises of Aristotle into those which teach the logical method (Posterior Analytics), those that contribute to that method (Categories, De Interpretatione, Prior Analytics) and those which demolish the method (Sophistical Refutations, Topics, Rhetoric, Poetics). In this division, although the content of Rhetoric is clearly not accepted, its position within the Organon is justified: it describes the method of hiding the truth not in order to use it, but in order to avoid it. Hence, the Rhetoric is part of the logical organon of philosophy in the way that the Sophistical Refutations or Topics is, namely, to teach about deceptive arguments and how to avoid them. Similarly, in their Prolegomena to Philosophy, both Elias and David enumerate rhetorical errors, which are corrected by philosophy. Rhetoric can therefore be used as a progymnasma or exercise for philosophy, since it makes use, on the one hand, of principles (proofs and divisions) that come from philosophy. 
to logic are interpreted with direct references to Aristotle's account in the Sophistical Refutations or Analytics, while passages from Aristotle's account of ethical definitions (Rhet. I.4-14) and of style (Rhet. III) are neglected. Interestingly, he interprets the account of emotions not as referring to the arousal of the emotions in an audience, but as offering additional topoi for arguing for the intentions of the person that commits an action (CAG XXI. 2 298, 27-299, 13). ${ }^{11}$

Like Stephanus, the Anonymous author is also interested in showing the consistency between the Rhetoric and other logical treatises, especially Prior Analytics, but unlike Stephanus, the Anonymous author offers a more complete commentary by further interpreting passages that are not immediately connected with Aristotle's theory of argumentation. Hence, when logic does not come into play, he is satisfied with showing the consistency of the rhetorical account with, for instance, the ethical account. Therefore, it seems that, while Stephanus' primary concern is to demonstrate that the Rhetoric is a logical treatise, the Anonymous author's primary interest is interpreting Aristotle ex Aristotele and thereby demonstrating the ways in which the treatise relates to the views expressed in other Aristotelian treatises.

This helps us also to draw conclusions regarding the aim of the two commentaries. In particular, the extensive use of Aristotelian logical and ethical terminology, together with the recognition that in the commentator's time one could find an abundance of material on rhetorical practice, lead us to the conclusion that the commentaries were not written in order to be used as handbooks for oration, but rather with the intention of preserving the treatise that has been rejected before. ${ }^{12}$ The fact that commentaries make textual emendations and

11 Another indication for Stephanus' view that Rhetoric is part of the Organon is his use of diagrammatic representations of syllogisms, which is typically seen in the byzantine commentaries on Aristotle's logical treatises. See C. RAmBouRG, Les diagrammes syllogistiques des scholies de Stephanos à la Rhétorique d'Aristote (CAG 21.2). Classica et Medievalia 63 (2012), 279-315. 12 This goes against the view in CoNLEY, Aristotle's Rhetoric (as footnote 1 above), who argues that both commentators were more interested in topics that have been central in the preceding rhetorical treatises, such as the definition of the art of rhetoric, and in topics that are more relevant to their contemporary rhetorical practice, such as epideictic or legal oratory, which is also mirrored in their use of contemporary terminology, and hence, concludes, that "their interests (or their readers' interests) were not particularly intellectual, but practical” (p. 39). However, the fact that both commentators make extensive use of technical logical vocabulary and presuppose that the reader is well-acquainted with the Aristotelian philosophy, together with the fact that they are often interested in issues of textual transmission of the text, indicates that they wrote their commentaries with rather intellectual interests, that is, aiming at preserving the treatise and at interpreting it in a way that integrates it into Aristotle's philosophical system. 
often supply the reader with information about previous interpretations of particular passages, further supports this conclusion. It seems, therefore, that the commentaries have not been written with the aim of immediate practical use the way handbooks for oratory would have been, although it seems probable that they were used as teaching material. Especially, the fact that the treatise is interpreted with priority to its logical elements can also confirm this suspicion, if we accept that the study of the Rhetoric followed the study of the other logical treatises, and that the readers of the commentaries were therefore well-acquainted with the terminology and concepts in Aristotle's theory of argumentation.

The features indicated above, especially the interpretation of the Rhetoric with reference to other Aristotelian treatises as well as the interest in preserving and improving the text are indications that the two commentaries are the products of the awakening of Aristotelian studies in Byzantium, which took place in Constantinople under the patronage of Anna Comnene. ${ }^{13}$ Although it has been already been suggested that the commentators are associated with Anna's initiative, this suggestion has not been explicated or proven. However, a close reading of the commentaries shows that their association with Anna's circle can be demonstrated not only through the fact that Anna supported the production of commentaries mainly on the Aristotelian treatises that have been neglected before, among them the Rhetoric, but also through information that we can gather from the commentaries themselves. In particular, the profile of the two commentators fits very well with what we know about the other scholars that belonged to this group: they have deep knowledge of the history of philosophy and of Rhetoric and also refer often to classical and late antique treatises which they integrate into their interpretation of particular passages taken from the Rhetoric. More importantly, both have very good knowledge of Peripatetic philosophy (especially of the Organon), while they are the authors of other commentaries on Aristotle's treatises as well. ${ }^{14}$ This expertise in Aristotle and in the production of a number of commentaries on the Aristotelian treatises, corresponds with what we expect from scholars belonging to the circle of Anna Comnene. Moreover, a passage that seems to be autobiographical offers additional evidence for the Anonymous' association with Anna: The Anonymous commentator refers

13 On Anna's patronage of Byzantine scholarship see R. BRownING, An unpublished funeral oration to Anna Comnene. Proceedings of the Cambridge Philological Society 8 (1962), 1-12. 14 Stephanus explicitly refers to his own commentary to the Ethics, while the Anonymous author of the commentary to the Rhetoric must be identified with the again Anonymous author of the commentary to Nicomachean Ethics VII, as has been shown by VoGIATZI, Commentaries (as footnote 7 above) 22-31. 
to a conflict for the acquisition of the throne, and suggests that he is associated with the losing party in this conflict (CAG 21.2 98, 23-27). This may be a direct reference to Anna's attempt to usurp the throne from her brother after their father's death in 1118, and her failure in doing so, after which she confined herself to a monastery and began her engagement with Aristotelian scholarship.

What has been said so far regarding the two extant commentaries, gives us the context of the production of commentaries on Aristotle's Rhetoric in 12th century Byzantium more generally. I take our conclusions from the examination of these two commentaries to be also applicable to the other cases of commenting on Aristotle's Rhetoric, as for instance, to the commentary and paraphrase that survived in fragmentary form. ${ }^{15}$ In particular, these fragmentary texts on the last chapters of the third book of the treatise, which are dated also in the middle Byzantine period and might have been part of a commentary and paraphrase on the whole treatise or of the entire third book, ${ }^{16}$ exhibit the same interests and aims as the extant commentaries examined above. First, their authors show similar interests as the Anonymous and Stephanus in interpreting the treatise with reference to other Aristotelian treatises, for instance, to the Nicomachean Ethics (327, 2; 329, 5), which can be an indication that the authors belonged to a certain school that studied the Rhetoric as part of a systematic curriculum that included the whole Aristotelian corpus. Second, the references to classical authors are also abundant (Homer, Plato, Plutarch, Demosthenes, Euripides, Herodotus, Isocrates), which, as in the Anonymous author and Stephanus, indicates that we are dealing with typical Byzantine scholars with interest in classical texts and late antiquity in its entirety. Finally, the author of the fragmentary commentary makes use of diagrams in order to illustrate the syllogisms, which are reminiscent of Stephanus' diagrammatic representations of Aristotelian rhetorical syllogisms ${ }^{17}$ and which point to the role that the author ascribed to the Rhetoric, namely as being a logical treatise.

It has already become clear that, Aristotle's Rhetoric was studied at least within the context of a group of scholars in Constantinople. It has also become clear that these scholars had in fact philosophical training, and hence, interpreted the Rhetoric with respect to its position within the Aristotelian philosophical system. What remains to be seen is whether even more commentaries (in addition to the four discussed so far) were dedicated to the Rhetoric in the 12th

15 RABE, Commentaria (as footnote 2 above).

16 Ibid.

17 See C. RAmbourg, Les diagrammes syllogistiques des scholies de Stephanos à la Rhétorique d'Aristote (CAG 21.2). Classica et Medievalia 63 (2012), 279-315. 
century, in which case we could definitely recognize a revival of interest in the treatise during this period.

\section{Commentators and teachers of Rhetoric in the 12th century}

Although no extant commentaries on Aristotle's Rhetoric have survived besides those written by the Anonymous author and by Stephanus, we can draw some conclusions about the existence of the teachers and the commentators that predate them based on information collected from the passages where the two commentators refer to their sources.

I will start with Stephanus, whose references to earlier interpreters of the Rhetoric give us also an indication of the relative dating of the two surviving commentaries. In particular, based on historical references found in the commentaries, we can infer that the anonymous commentary was written earlier than the one by Stephanus. ${ }^{18}$ Yet this dating is further supported by the observation that Stephanus seems to draw on the Anonymous author and to refer to views expressed in his commentary. What remains unclear is whether it is the anonymous commentary itself that he has read or another text, which was somehow related to the Anonymous author's commentary (or maybe its source). However, given the fact that Stephanus' report of earlier commentaries often repeats the same vocabulary and examples that are found in the Anonymous' commentary, ${ }^{19} \mathrm{I}$ find it more probable that Stephanus, who lived in the same time and in the same place as the Anonymous, has read - maybe among other commentaries - the Anonymous commentary itself and that it is this particular text that he addresses, or at least group of texts, to which the Anonymous' commentary belonged. A closer examination of some of these passages can help in understanding whether Stephanus was aware of more than one of the commentaries written before his own:

18 In particular, the Anonymous, who lived in Constantinople in the first half of the $12^{\text {th }}$ century, wrote his commentary around 1118-1122, and hence precedes Stephanus, who composed his commentary in the years 1122-1126. See Vogiatzi, Commentaries (as footnote 6 above), 12 -18; see also Wolska-Conus, Scholies (as footnote 2 above), 599-600.

19 See the following passages: 265, $12-16 ; 269,13 ; 270,28 ; 272,5-6 ; 273,14$ ff.; 274, 11 12; 277, 28; 282, 16; 283, 16; 288, 27 ff.; 290, 20 ff.; 304, 30; 305, 30; 311, 32; 320, 26. 
T.1 Hence, this has been interpreted well by me with the help of God, whereas the others wandered from the truth fully ${ }^{20}(265,12)$.

T.2 And we made these clear as much as we could, leaving aside for now all the published interpretations of this passage written by the philosophers before us $^{21}(290,21-23)$.

T.3 This [matter] has caused many issues to our teachers and interpreters, but I believe I make it clear in the present occasion ${ }^{22}(304,30)$.

T.4 This statement also created confusion to the interpreters; but in this way, I believe, this will also be rightly grasped ${ }^{23}(305,31)$.

Upon closer inspection, we find that Stephanus usually refers to previous interpreters not to merely report on the various readings of specific passages, but in order to criticize their interpretation. For instance, in the above-cited passages, the commentator refers to previous exegeseis of the treatise to make clear how the previous scholars failed to understand the treatise correctly. First, a note should be made here regarding the use of the term exegesis. Exegesis means literally explanation or interpretation and usually refers to an extent text, that is, a full commentary of a treatise as opposed to a comment on a single passage. ${ }^{24}$ Byzantine commentators, among them Stephanus and - as we will see later the Anonymous author, refer to their own work as exegesis, and we can take this to mean their production of extent commentaries in a written form. It is clear that the term exegesis refers to written commentaries as opposed with views expressed merely in oral form, for instance those that are within a class, when scrutinizing passages such as [T.3], where exegesis is contrasted with the work of teachers. Moreover, [T.2] makes it clear that the interpretations that Stephanus refers to must be written commentaries, and in fact, published

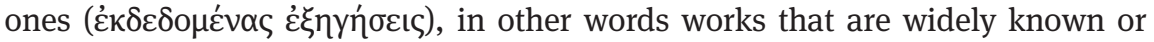
available.

Second, we can turn to the main question that is relevant to our current purposes, and focus on the number of exegeseis that Stephanus has in mind.

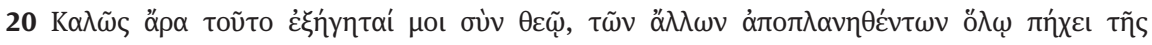
$\dot{\alpha} \lambda \eta \theta \varepsilon \dot{\alpha} \alpha$.

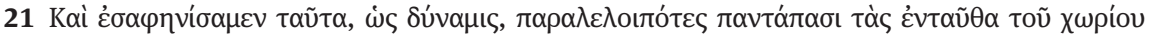

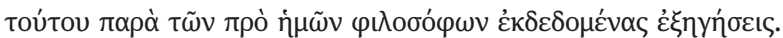

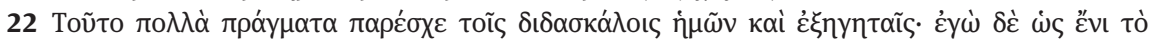

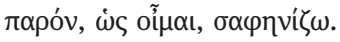

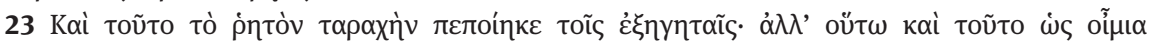

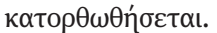

24 This would be called scholion; see later on the Anonymous. 
Although we cannot say for sure how many commentaries Stephanus had read and made use of when writing his own commentary, the plural form that he uses for referring to earlier interpretations indicates that he has in mind more than one commentary. The fact that he refers also to teachers shows that, at least within a group of scholars, the Rhetoric was being taught, an insight that enhances the possibility that more than one scholar worked on the treatise before Stephanus. In fact, most of his criticism of previous interpretations seems to be directed at the Anonymous commentary, or at least to one of Anonymous' sources. However, there are cases, for instance the passage in [T.1], where the criticized view is not found in the Anonymous text. Therefore, we can be sure that Stephanus read more than one commentary before writing his, and that he knew at least one of the teachers who taught Aristotle's Rhetoric.

Given that Anonymous wrote his commentary shortly before Stephanus, the information that he gives us regarding the preceding production of commentaries on Aristotle's Rhetoric can be more helpful for giving a more definite answer on the number of commentaries dedicated on this treatise in the 12th century. Here are some references to his sources:

T.5 I found a scholium interpreting this thus, namely that this enthymeme is said [fallaciously] due to the verbal expression, because the syllogism is defect; for we stated the conclusion without stating in advance [the premises], [since] an enthymeme is an incomplete syllogism having one defect premise $^{25}(147,32-34)$.

T.6 I found a scholium in one of the most worm-eaten books, which is rather right, such as $[\ldots]^{26}(218,27)$.

T.7 However, the teacher interpreted the statement thus, namely that he called such a [fallacious enthymeme] "due to the verbal expression" as being the same as "due to the form of the verbal expression" 27 (147, 22-25).

T.8 The philosopher, however, interpreted thus the statement that says that [the enthymeme is] from a few and often less [premises] than those of the first

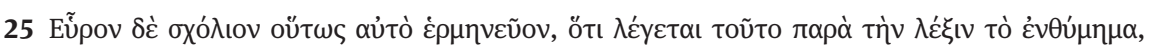

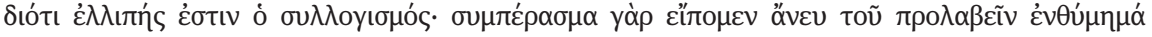

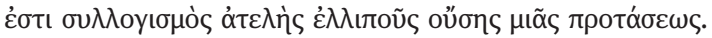

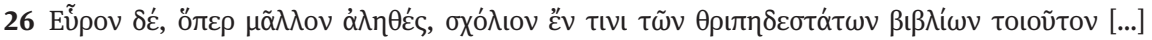

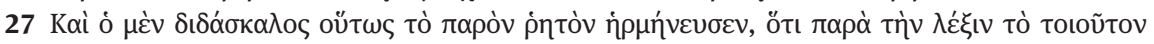

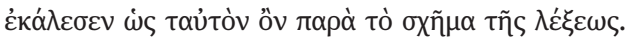

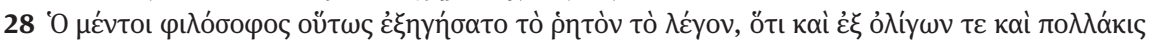

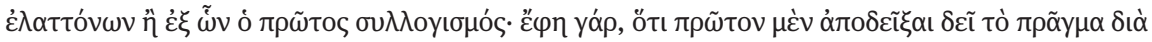
$\lambda$ 
syllogism. For he says that first one needs to prove the thing through long arguments, and then to form syllogisms with shorter arguments ${ }^{28}(3,2-4)$.

T.9 The metropolitan interpreted thus: "antimimicking" in so far as the desire of the soul is contrary and counteracting to the wish of the body ${ }^{29}(176,15-$ 17).

As we see in the above-cited passages, the majority of Anonymous' references to his sources consist of simple reports of other views and not of evaluations or criticisms of these views. In other words, the commentator often cites previous interpretations of the treatise without stating whether he agrees or disagrees with them. All in all, we find references to four types of sources. The passages [T.7]-[T.9] are examples of the first three types of sources: Anonymous' interpretations are said to come from a certain teacher or philosopher or a metropolitan and are cited as concrete views expressed by a particular person. ${ }^{30}$ In fact, I take all three types to refer to the same person, since the commentator always uses the definite article when citing this teacher/philosopher/metropolitan, especially when reporting what "the teacher said," or what "the philosopher explained," which suggests that he expected the reader to recognize the identity of this teacher or philosopher.

Regarding the content of these citations of earlier interpretations, the references to this earlier teacher/philosopher/metropolitan do not make use of terminology that explicitly hints at written commentaries. More specifically, except for [T.8], to which I will come back later, there are no explicit references in the Anonymous to exegeseis, namely "published" or circulating commentaries, at least of which the Anonymous knew. Unlike Stephanus' commentary, where we found many references to $\dot{\varepsilon} \xi \eta y \eta \tau \alpha$, namely to authors of written texts dedicated to the Rhetoric, Anonymous refers to previous interpretations of particular pas-

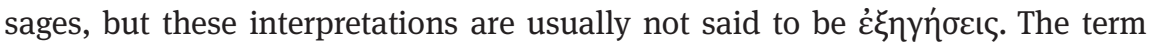
exegesis is used by the Anonymous author mainly with reference to his own

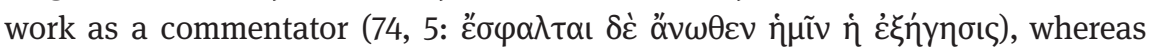

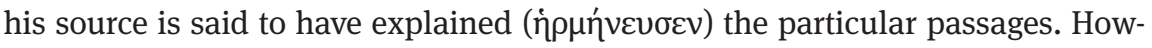
ever, the term hermeneia does not necessarily refer to written commentaries rather than to views expressed orally. Although it might be the case that these interpretations were delivered in the form of a written text, we cannot be sure

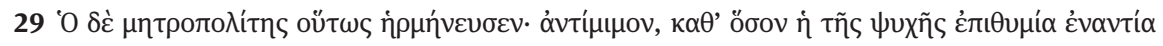

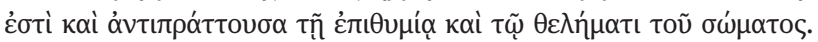

30 Unlike Stephanus' vague references to "teachers" and "interpreters", the Anonymous seems to have in mind particular scholars, whom the reader would probably recognise. 
yet. What we can be sure of, is that there is at least one person that worked on Aristotle's Rhetoric and offered an interpretation of at least some passages, if not of the whole treatise, while this teacher might also be the author of a written commentary on the treatise. Moreover, these references to a teacher further confirm the suspicion that Aristotle's Rhetoric was being taught in rhetorical and philosophical schools before or at the Anonymous' time.

We can now turn to [T.8], which is the only reference in the Anonymous author to a previous exegesis on Aristotle's Rhetoric. Should we suppose that this exegesis is a written commentary as the commentaries by the Anonymous author and Stephanus that the authors themselves call exegeseis, or as the "published" exegesis to which Stephanus referred? I think that the fact that both Anonymous and his near contemporary Stephanus (and other contemporary authors) use the term exegesis to refer to written texts, is a good reason to infer that the exegesis that we read here about is in fact a commentary, either a complete or a selective one (namely as the one written by Stephanus). This exegetical treatise needs not differ from the hermeneiai of the other passages, but it can also be the case that the Anonymous always draws from the same single source, which also fits with my suggestion that the teacher/philosopher/metropolitan is one and the same person. Thus, we can conclude, that the Anonymous' citations of earlier interpretations throughout his commentary come from a single source which is a written commentary.

If we further examine the cited interpretations of this particular philosopher, we can draw the same conclusions that we reached above regarding the aim and context of the commentaries written by Stephanus and the Anonymous author. In particular, given that the interpretations attributed to this source are in most cases philosophically interesting and make often use of complex Peripatetic notions, it seems that the source behind these references is a person well-acquainted with the Aristotelian philosophy, and hence rightly called "the philosopher." Moreover, if he is literally a teacher of the Anonymous author, then he must have also written his commentary at the beginning of the 12th century, and might have even been part of the group of scholars patronized by Anna Comnene.

If this is right, [T.9], which is the only more informative reference found in the Anonymous author, might reveal some further evidence regarding the identity of the source. In this passage, the Anonymous author does not attribute the cited view to a philosopher or teacher, but to a metropolitan. This metropolitan cannot be identified with Stephanus, not only on the basis of the later dating of the latter, but also because we fortunately have Stephanus' interpretation of this particular passage, and it differs from the reported interpretation of the 
metropolitan. ${ }^{31}$ We cannot draw more precise conclusions regarding the identity of this metropolitan, but especially if we accept that the three variations "teacher," "philosopher," and "metropolitan" refer to the same person, we can suggest that this person must be a well-known figure that a reader of the commentary would recognize without further explication. I will come back to this issue below.

The fourth type of references to Anonymous' sources are the scholia. ${ }^{32}$ The term is used contemporarily to refer to the marginal annotations of the manuscripts and it seems that this is also the meaning of the term when used in the Anonymous author. In particular, all of the 15 citations of scholia found throughout the commentary, are announced in the same way: "I found a scholion that reports/states etc." I take this introduction to the quotations to be clear evidence that we have to do with single comments rather than with an extant text, ${ }^{33}$ and that in fact such comments that are taken from the margins of the manuscripts that the Anonymous had before him. I am led to this conclusion mainly by the fact that he always points out that the scholion is something that he himself came across or found, which suggests that he read them while consulting a manuscript. In fact, we know for sure that he had access to more than one manuscript of the Rhetoric, since he often makes textual emendations based on different writings "found" in different manuscripts. Unfortunately, we are not able to identify either the exact manuscripts that he used for making the textual emendations, or the manuscripts that entail the particular scholia that he cites.

We can turn now to the additional information that is available regarding the production of commentaries in the 12th century. In the previous section, I briefly presented a passage from the commentary on the Sophistical Refutations

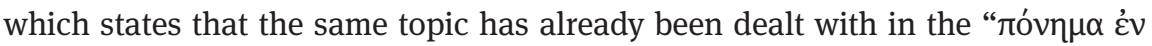

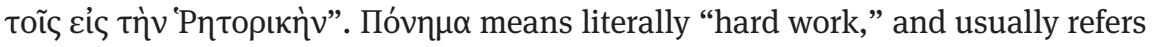

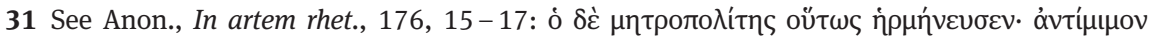

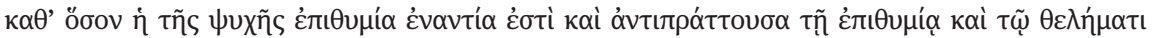

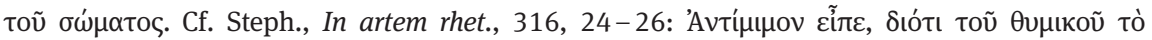

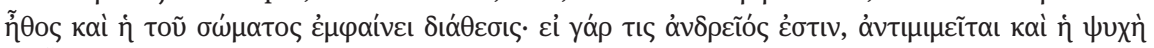

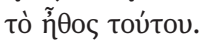

32 For all references to scholia see CAG 21.2, 147, 23; 147, 32; 150, 25; 203, 27; 206, 16; 206, $28 ; 207,22 ; 221,22 ; 230,6 ; 232,21 ; 241,31 ; 250,25 ; 250,5 ; 254,14 ; 259,3$.

33 However, I should note here that the difference between a commentary and scholia is not always clear, since the commentaries were initially written in the margins of the manuscripts that entailed the treatises in question. Hence, the extant commentaries were not written initially independently of the commented text, but in the margins around the text. However, I take the references to scholia found in the Anonymous not necessarily to refer to such an extent commentary, but probably to single annotations, due to the language that the Anonymous uses for referring to them. 


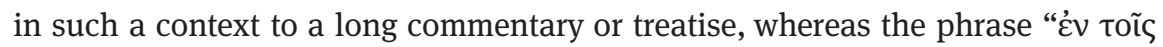

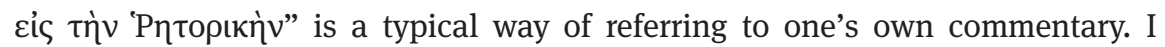
therefore believe, that we can accept that the author of the commentary on the Sophistical Refutations was also the author of a commentary on the Rhetoric. ${ }^{34}$ This commentary, as already mentioned, had been long attributed to Michael, the metropolitan of Ephesus, who probably lived in the first half of the 12th century, also belonged to the circle of Anna Comnene, and was the author of various commentaries on other Aristotelian treatises. Although the attribution of the commentary on the Sophistical Refutations to Michael has been recently questioned, ${ }^{35}$ one cannot overlook the fact that this description of the commentator's profile fits well with the Anonymous' allusion to a metropolitan. If it is not by coincidence that another author, also a metropolitan, wrote a commentary on the Rhetoric, then it seems that the Anonymous author's reference supports the attribution of the commentary on the Sophistical Refutations to Michael.

However, independently of whether we attribute the commentary on the Sophistical Refutations to Michael or to another author (who would have more or less a similar background as that of Michael), we must conclude that the aforementioned commentary on Aristotle's Rhetoric is an additional commentary that is now lost, whereas it seems very possible that it is this commentary that the Anonymous refers to in [T.9] as the interpretation of a metropolitan.

Besides the two extant commentaries, the information collected based on them, the fragments of a commentary and of a paraphrase, and the reference in the commentary on the Sophistical Refutations, we can also infer the existence of some additional commentaries on Aristotle's Rhetoric from some later texts that apparently made use of them. For instance, traces of a Byzantine interpretation of Aristotle's Rhetoric are found in the almost contemporary work of Eustathios, a scholar who lived in 1115-1195 and became the metropolitan of Thessaloniki. Eustathios is mostly known for his commentaries on Homer, in which he often cites or refers to other authors. In fact, there are many passages in which Aristotle's treatises are quoted, among them Rhetoric. ${ }^{36}$ However, as D. REINSCH

34 The commentary on the Sophistical Refutations shows also other passages knowledge of the

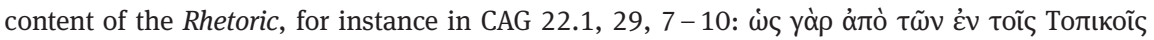

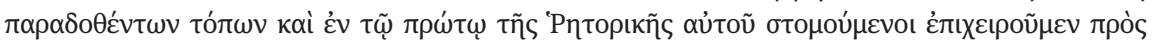

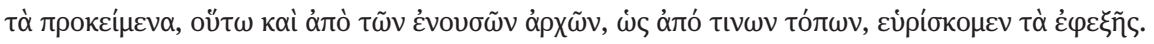
35 See Moore, Iter psellianum (as footnote 8 above), 560.

36 D. ReINsch, Über einige Aristoteles-Zitate bei Eustathios von Thessaloniki, in F. Paschke (ed.), Überlieferungsgeschichtliche Untersuchungen, Berlin 1981, 479-488 gives an accurate 
has shown, his citations from Aristotle's Rhetoric have not been taken from the original text itself, but rather from Byzantine commentaries. Specifically, Eustathios refers to the Rhetoric four times, three of which are supposed to be quotations from II.23, but since the vocabulary used does not correspond completely with the Aristotelian text, it seems rather probable that Eustathios quoted the passages while looking at a later paraphrase or commentary of the treatise. The question that arises and is relevant to our current purposes is whether Eustathios uses the commentaries that are already known to us or a commentary that is now lost. Fortunately, D. REINSCH analyzed these passages and convincingly showed not only that Eustathios' source is not Aristotle himself, but also that it is a commentary distinct from Anonymous or Stephanus. In addition, because of the similarity of Eustathios' text with both the Anonymous and Stephanus, he suggested that all three authors might rely on a paraphrase of the treatise that is now lost. Unfortunately, we cannot make any assumptions regarding the identity of the author of this commentary or paraphrase, namely whether it can be one of the fragmentary commentaries or another commentary or paraphrase of the treatise. We can also not evaluate with certainty the relation of this author to the two extant Byzantine commentaries, although the similarity between Eustathios' quotations and the two Byzantine commentaries can indicate that the latter were somehow related to Eustathios' source. Finally, although I included Eustathios' source in the section on 12th century commentaries, it is not clear whether it was actually written in this century. The afore-mentioned similarities might indicate that it was written around the same period as the commentaries of Anonymous and Stephanus. In any case, the 12th century is the terminus ante quem, since this is the time of Eustathios' use of it.

In summary, we have seen that the first surviving texts to comment directly on Aristotle's Rhetoric are the two Byzantine commentaries written in the 12th century by an Anonymous author and by Stephanus, and the fragments of an additional commentary, and a paraphrase of the treatise dated from the same period. From these commentaries, we also learned about the existence of other teachers, commentators or scholiasts who worked on the Rhetoric, which appear to have been the sources for the Anonymous author and Stephanus. Additionally, we inferred the existence of additional commentaries based on references found in the commentary on the Sophistical Refutations, as well as based on Eustathios' references to the Rhetoric in his commentaries on Homer. This study has brought us to the conclusion that, although the Rhetoric was not as popular as

list of such references to Aristotle in Eustathios' commentaries on Iliad and Odyssey, and analyses Eustathios references to Aristotle's Rhetoric. 
other Aristotelian treatises, and although our current knowledge of the exact number of commentaries produced is limited, we can still see that the study of the treatise was revived in the 12th century, and that the treatise was read and commented on like never before.

\section{Philosophy, Rhetoric and Education in Byzantium}

What remains to be seen is the reason for this revival of interest towards Aristotle's Rhetoric. Although an explanation of all parameters that played a role is a complicated issue, I will make an attempt to address some points that seem to have contributed to this revival. First, I have already referred above to the group of scholars patronised by Anna Comnene with the task to study and write commentaries on Aristotle's treatises, especially the ones that have not been commented on before. This led to the production of a number of commentaries on less famous Aristotelian treatises, e.g. Biological works, Nicomachean Ethics, Politics. We can be sure that this initiative played an important role in the flourish of the Aristotelian studies by promoting both the philosophical analysis of the texts and their philological editing, including the production of numerous copies of the treatises. It comes, therefore, as no surprise that the commentaries on the Rhetoric that we are studying are dated exactly in the time of this flourish of Aristotelian studies and exhibit the same points of interest as other commentaries of this time. ${ }^{37}$

However, Anna's initiative seems not only to be just one of the parameters, but a secondary one, since one is left with the question of how Anna and her contemporaries got interested in Aristotle in the first place. A look at the Byzantine higher education of that time seems to yield an answer to this question. In particular, two higher education institutions of the time, namely the "School of Philosophy" and the "Patriarchal School", seem to be responsible for the promotion of the study of classical philosophy and Rhetoric. The School of Philosophy was established in the eleventh century under the head of Michael Psellos, who took the title hypatos tôn philosophôn, a title that was later inherited by the following holders of this post, for instance Ioannes Italos, the teacher of Eustratios of Nicaea, who belonged to the circle of Anna Comenne. The Patriarchal School, although founded already in the fifth century, became during the twelfth century

37 I refer to the commentators' interest in studying Aristotle as a whole and in showing the consistency of Aristotle's teachings. 
the "centre of the Byzantine culture." 38 According to Browning, the school was directed primarily to secular education, especially grammar and Rhetoric. Among its posts we can find one of the maistôr tôn rhetorôn, probably corresponding to a professor of rhetoric. ${ }^{39}$ In fact, many of the names that we have examined above seem to be somehow connected to this school, or at least to some of its branches. Stephanos Skylitzes was appointed at the school in the church of St. Peter and Paul, Eustratios of Nicaea was probably attached to the school of St. Theodore, and Eustathios of Thessaloniki was one of the teachers at the school..$^{40}$ Hence, it becomes clear that, up to a certain extent, the occupation with Aristotle and classical studies in general was connected with the existence of posts that taught classical texts and promoted their study. In other words, the very existence of the posts of the maistôr tôn rhetorôn and the hypatos tôn philosophôn and especially their crucial role in the Byzantine higher education, seems to be directly connected with the revival of the study of both philosophy and Rhetoric in the Byzantine period. Especially given the fact that these posts were appointed directly by the Church or the Emperor, we can assume that this revival was promoted by the emperors of the time. ${ }^{41}$ However, the holders of these posts were only some of the scholars who were interested in and work on such texts.

Regarding the study of philosophy, in addition to the consuls (hypatoi), whose duties included teaching and other academic activities, such as the preparation of commentaries, there is great number of Byzantine scholars who also taught and commented on Aristotle's treatises, as for instance the scholars I

38 R. BRownING, The Patriarchal school at Constantinople in the twelfth century. Byzantion 32 (1962), 167 -202: 168.

39 See the late Byzantine title rhetôr tôn rhetorôn.

40 BRowning, Patriarchal school (as footnote 38 above) argues that both the Church of St. Theodore and the Church of St. Peter at Paul, and especially the schools attached to them, were under the control of the Patriarchate. See N.G. Wilson, Scholars of Byzantium. London 1996, 197 on Eustathios' appointment as a teacher of rhetoric.

41 On the role of the church in $12^{\text {th }}$ century higher education see M. ANGOLD, Church and society in Byzantium under the Comnenoi 1081-1261. Cambridge 1995, 50 -60; A. MARKopoulos, In search for 'higher education' in Byzantium. ZRVI 50 (2008), 29-44. In fact, Markopoulos argues elsewhere that there is no such thing as "higher education" in Constantinople in the sense of an organised system that lasted throughout the centuries, but every instance of higher education can be traced back to private initiatives, including initiatives by particular emperors, but did not last in time: A. MARKopoulos, Education, in E. Jeffreys/J. Haldon/R. Cormack (eds.), The Oxford Handbook of Byzantine Studies. Oxford 2013, 785-795: 790-791. 
mentioned above as belonging to the circle of Anna Comnene. ${ }^{42}$ The study of Aristotle's Rhetoric may well have been part of the Byzantine scholars' preoccupation with Aristotle, which produced the commentaries on the Aristotelian works that have come down to us. In this sense, the Rhetoric was studied along with the other Aristotelian treatises as part of the Aristotelian corpus.

Moreover, the revival of the study of Aristotle's Rhetoric is probably connected not only with the role of the philosophical studies in Byzantium, but also with the important role of the study of Rhetoric. As I mentioned above, Rhetoric was being taught in the schools of the empire as part of the higher education and the post of the maistôr tôn rhetorôn was created, with duties that were likely similar to those of the consul of the philosophers. Although the study of Rhetoric mostly included late antique rhetorical texts, such as the Progymnasmata and the treatises of Hermogenes, as well as later commentaries on these treatises, ${ }^{43}$ it might be the case that Aristotle's Rhetoric also attracted the attention of the rhetoricians during this time.

Therefore, the historical reality that philosophy and Rhetoric were being taught and also played important roles in the Byzantine educational system seems to, at least partly, explain the increase in interest in Aristotle, in particularly in his treatise the Rhetoric. In such a context of promotion for philosophical and rhetorical studies, the occupation of the 12th century scholars with the Rhetoric led, on the one hand, to the copying of manuscripts that entailed the treatise and so made the text more easily available, ${ }^{44}$ and, on the other hand, to the production of commentaries that analysed its content. This situation is also depicted, as we have already indicated, by the two commentators on Aristotle's

42 For an overview of the post of the "consul of the philosophers" from its beginning till the $14^{\text {th }}$ century, see C.N. Constantinides, Higher education in Byzantium in the thirteenth and early fourteenth centuries (1204-ca. 1310). Nicosia 1982, 113-114, who offers also information on other Byzantine scholars that taught philosophy. On the Byzantine philosophers of this period see WiLson, Scholars (as footnote 40 above).

43 On the post of the maistôr tôn rhetorôn in the various schools see BRowning, Patriarchal school (as footnote 38 above) and Constantinides, Higher education (as footnote 42 above), 51-54. Regarding the rhetorical studies and the texts they included see ibid. $154 \mathrm{ff}$.

44 As Conley, Aristotle's Rhetoric (as footnote 2 above), 38 pointed out, the number of manuscripts containing Aristotle's Rhetoric up to the $12^{\text {th }}$ century was very small, and the treatise was not easily available. For this reason, we can conclude that the commentators of the $12^{\text {th }}$ century contributed greatly to the survival of the treatise. Cf. WiLson, Scholars (as footnote 40 above) 184. 
Rhetoric who report the teaching of Aristotle's treatises as well as the existence of manuscripts that contain comments on the Rhetoric. ${ }^{45}$

45 Cf. G. A. KenNEDY, Greek rhetoric under Christian emperors. Princeton 1983, 318, who refers to lecturing on Aristotle's Rhetoric in the Alexandrian school. 